\title{
Bioassay of the Isolated Volatile Compounds from Mice Urine and Its Phagostimulant Effect.
}

\author{
Rady, G. H*; Mahmoud, E.A**; Mohamed, Gh. R*. and Elbath, M.A*. \\ * Plant Protection Dept., Fac. of Agric., Moshtohor, Benha Univ. \\ **Dept of veterinary Hygiene And Management, Fac. of Veterinary Medicine, Benha Univ. \\ Corresponding author: moemen.elbath@fagr.bu.edu.eg
}

\begin{abstract}
This study was designed to identify the urinary volatile compounds present in urine of male and female mice Mus musculus in order to detect the most attracting compounds to both sexes to use these compounds as a sex attracting material to enhance the efficiency of rodent bait. The urine of adult male and female mice were collected and analyzed by GC-MS. The result of chemical analyze revealed presence of many volatile compounds in urine of both sexes. From the identified compounds Phenol, 3-ethyl, 1,8-Nonadien-3-ol, 5-Octadecenal, Octadecane, 5methyl- and 4-ethyl phenol were detected in male urine and Phenol, 2-ethyl- (CAS), and Phenol, 3-ethyl- were detected in female urine. Synthetic compounds similar to identified ones were purchased, different concentrations $(0.5,1,5,10$ and $100 \%)$ were prepared from each chemical compound and the respose of tested animals toward these compounds in different concentration were evaluated by using Y - maze apparatus. The number and duration of visits of animal toward chemicals were recorded. Obtained results showed that Phenol, 2-ethyl- (CAS), Phenol, 3-ethyl and 4-ethyl phenol are the most attracting chemical compound in males, while 4-ethyl phenol and 2-ethyl(CAS), Phenol is the most effective one in females. Food consumption was affected in both sexes by mixing of the isolated compounds individually by concentration 1 and $5 \%$ with animal diet, the highest food consumption in both sexes was scored by addition of $20 \%$ solution from 4 -ethyl phenol $5 \%$.
\end{abstract}

Key word: Mice urine, volatile compound, attractiveness, phagostimulant.

\section{Introduction}

Rodents are considered one of the worldwide pests that affect human health, welfare, agricultural crops and stored food grains causing great economic losses. Among rodents, rats which are the dominant and highly infectious pests which infest human housing, sewers, animal shelters, day care facilities, warehouses, outdoor recreational areas; furthermore, they serve as a reservoir of several important vectors of diseases like plague, leptospirosis, rickettsia pox, rat bite fever and marine typhus fever Jackson (1987). Thus efforts have been made to control rats and mice in some of the large metropolitan areas by using chemical rodenticides over the past few years, however chemical control methods are made less effective by rodent's bait shyness, although no specific method has overcome the poison bait shyness of rodents.

All mammals emit chemical cues in their environment via urine, saliva, or specialized scent glands, but urine is the major source of all mammalian chemo-signals involved in releaser and primerpheromonal effect Archiraman and Archunan (2006). Rodents have effective olfactory communication between male and female and this play a vital role in their high reproductive fitness. Attempts have been made to use urine to reduce the shyness behavior. The conspecific urine is able to mask the poison aversion and bait shyness behavior in the desert gerbil., so adding mice urine to poison bait successfully eliminates bait shyness behavior this indicate that mice urine contains volatile compounds that are involved in reducing the poison bait shyness kumari and Prakash (1980).
Therefore the present study was undertaken to characterize mice urinary compounds, to investigate the bioactivity of the identified compounds and to analyze the biological significance of the identified compounds with a view to producing a pheromonal trap to contributes rodent pest management programs.

\section{Materials and methods}

\section{Animals}

This work was fulfilled at the Plant Protection Department, Faculty of Agriculture, Benha University and carried out on adult male and female mice (Mus musculus), which were collected from nearby villages and acclimatized to laboratory conditions for 2 week prior to the experimental study. The animals were housed in metallic cages, supplied with enough food containing $21 \%$ protein, $4.59 \%$ fat and $4.20 \%$ fiber and water. Only from the capture mice the apparently healthy adult animal were selected, sexed, caged and given a reference number, beside that twenty of mature mice, males and females were let to multiplty to supply the experiment with the needed individuals.

\section{Urine \\ collection}

The urine samples were collected from the adult male and female mice by a specific type of cages (metabolic cages). Measuring $30 \mathrm{~cm}$ depth and $25 \mathrm{~cm}$ diameter the cage was cylindrical in shape \& supplied with a door at the top and the floor was grid to facilitate separation of fecal matter from urine.

Extraction of the volatile compound from the urine samples 
Extra pure dichloromethan ( DCM ) was used to extract the volatile compounds from the urine samples and this occure by mixing $100 \mathrm{ml}$ of urine with $100 \mathrm{ml}$ DCM in separation funnel and shaking the mixture well for $30 \mathrm{~min}$.. after that time two layer were formed, the upper layer (polar layer ) was discarded with pheromone, while the lawer one was the organic layer. The filtrated extract was immediately analyzed by GC-MS.

\section{GC-MS analysis}

GC-MS was performed on Thermo Scientific Trace 1310 Gas chromatograph attached with ISQ LT single quadrupole mass spectrometer. X Calibur Road mup software ( windows xp ) was used for data acquisition and processing. The GC was equipped with DB5- ms, 30m, 0.25mm ID (J\&W Scientific). Helium was used as the carrier gas, at a flow rate of $1.5 \mathrm{ml} / \mathrm{min}$. For each test, $8 \mu \mathrm{l}$ of extracted dichloromethane were injected into the GC-MS. The temperature of the injector was set at $280^{\circ} \mathrm{C}$, and the electron impact ionization (EI) temperature was set at $300^{\circ} \mathrm{C}$. The oven temperature was programmed as follows: $50^{\circ} \mathrm{C}$ initially, increasing $5^{\circ} \mathrm{C} / \mathrm{min}$ to $200^{\circ} \mathrm{C}$, and then $1.5^{\circ} \mathrm{C} / \mathrm{min}$ to $230^{\circ} \mathrm{C}$, and finally $5^{\circ} \mathrm{C} / \mathrm{min}$ to $250^{\circ} \mathrm{C}$, where it was maintained for $6 \mathrm{~min}$. The relative amount of each component was reported as the percentage of the ion current. We identified unknown volatile compounds by probability-based matching using the computer library (Nist-msms, Nist-msms2, Nist-ri, Nistdemo and wiley9 Mass Spectral Library).

\section{Odor preference test}

The chemical profile of analyzed urine samples revealed presence of main six compounds, which were Phenol, 2-ethyl- (CAS), Phenol, 3-ethyl-, 4-ethyl phenol, 5-Octadecenal, 5-Octadecenal, 1,8-Nonadien3 -ol. Five concentrations $(0.5,1,5,10$ and $100 \%)$ from each chemical compound were prepared and the biochemical activity for each concentration was tested by using odor preference test by $\mathrm{Y}$ maze apparatus with individuals of mature male mice and mature female mice. The Y-maze apparatus was measured $(150 \times 15 \times 15 \mathrm{~cm})$, the sides and floor of the Y-maze apparatus were made of tin sheets, while the top was an iron mesh. The size of the central arm was about 80 $\mathrm{cm}$ long and $15 \mathrm{~cm}$ wide. The remaining 2 choice arms were each $75 \mathrm{~cm}$ long and $15 \mathrm{~cm}$ wide. A clean glass slide was dipped in each concentration identified compounds separately then put in the passage (no.1). The tested mice (male and female) were put in the main passage and given the opportunity to enter to any of the two passages. The number of visits and the time spent near the identified compounds by the test animals were assessed for 15 minutes, the test was repeated three times for each group by a new individual in each test to avoid adaptation.
Effect of mixing of identified compounds with formulated feed on food Consumption

Bioassay revealed that concentrations of 1 and 5 $\%$ from all tested chemical compounds were the least attracting concentrations, these results encouraged us to tested the palatability of these compound when mixed with rodent ration, and for doing this fifty grams of mice feed were put in a plastic container and efficiently mixed with five $\mathrm{ml}$ of freshly prepared sample, mixed food was put in front of tested rats for 24 hours for estimation of daily food consumption for each 100 grams body weight. This experiment was repeated again but by using $10 \mathrm{ml}$ of freshly prepared sample with the same amount of feed. The object of this experiment was to test the palatability \& phagostimulant effect of these compounds when mixed with mice food matrial to use them for elimination of bait shyness during preparation of the chemical bait as method of rodent control

Analysis of variance in Two-way ANOVA was carried out using SAS procedure guide (SAS, 2004). Significant differences among means were tested using Duncan multiple rangiest (Duncan, 1955).

\section{Results and discussion}

\section{GC-MS analysis}

Analysis of collected urine samples from male and female mice by GC-MS revealed present of many volatiles compounds in the urine of both sexes. In females we could detect presence of Phenol, 2-ethyl(CAS) and Phenol, 3-ethyl- table (1) and figure (1), while in male we could detect presence of Phenol, 3ethyl-, 1,8-Nonadien-3-ol, 5-Octadecenal, Octadecane, 5-methyl- and 4-ethyl phenol table (2) and figure (2).

Carful observation on obtained results revealed presence of a common volatile material, Phenol, 3ethyl- in the urine of both sexes, while Phenol, 2ethyl- (CAS) present only in female mice and not detected in the male urine while male Mus musculus urine contained 1,8-Nonadien-3-ol, 5-Octadecenal, Octadecane, 5-methyl- and 4-ethyl phenol which are not observed in female urine. These results nearly agree with Achiraman and Archnan (2002); Novotny et al (1985); Cavaggioni and MucignatCaretta (2000).

Another important observation about chemical structure of the detected chemical compounds as shown in figures(1-2) and tables (1-2) is that the carbon atoms of the urine volatile compounds are ranged from 6 as in phenol (C6H6O) and 19 as in octadecane,5 methyl (C19H40) other isolated components locating in-between. The present observation gains support from reports related to pheromone identification done by Dominic (1991) who stated that pheromones usually contain 5-20 carbon atoms and must be volatile to reach the receiver. 
Table 1. List of compounds identified in female Mus musculus urine.

\begin{tabular}{ccccc}
\hline Compound name & $\begin{array}{c}\text { Retention time } \\
(\mathbf{m i n})\end{array}$ & Mol. wt & $\begin{array}{c}\text { Molecular } \\
\text { formula }\end{array}$ & Area\% \\
\hline $\begin{array}{c}\text { Phenol, 2-ethyl- (CAS) } \\
\text { Phenol, 3-ethyl- }\end{array}$ & 13.73 & 122 & C8H10O & 47.22 \\
\hline
\end{tabular}

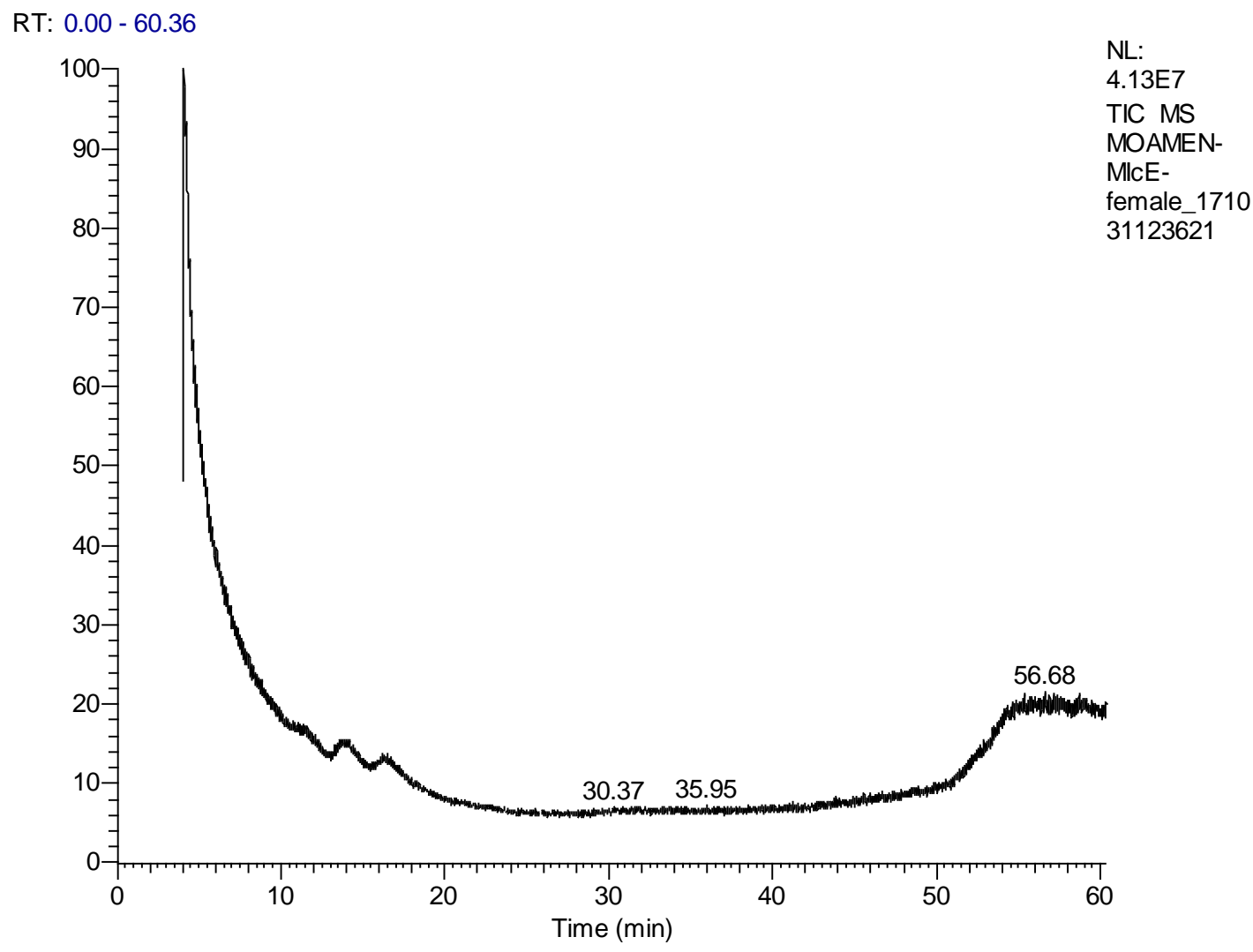

Figure 1. Gas-chromatographic profiles of the urine of female Mus musculus.

Table 2. List of compounds identified in male Mus musculus urine.

\begin{tabular}{lcccc}
\hline Compound name & Molecular formula & Mol. wt & Retention time(min) & Area\% \\
\hline Phenol, 3-ethyl- & C8H10O & 122 & 12.79 & 28.21 \\
1,8-Nonadien-3-ol & C9H16O & 140 & 14.86 & 15.99 \\
5-Octadecenal & C18H34O & 266 & 21.92 & 29.41 \\
Octadecane, 5-methyl- & C19H40 & 268 & 25.80 & 0.87 \\
4-ethyl phenol & C8H10O & 122 & 31.38 & 4.33 \\
\hline
\end{tabular}




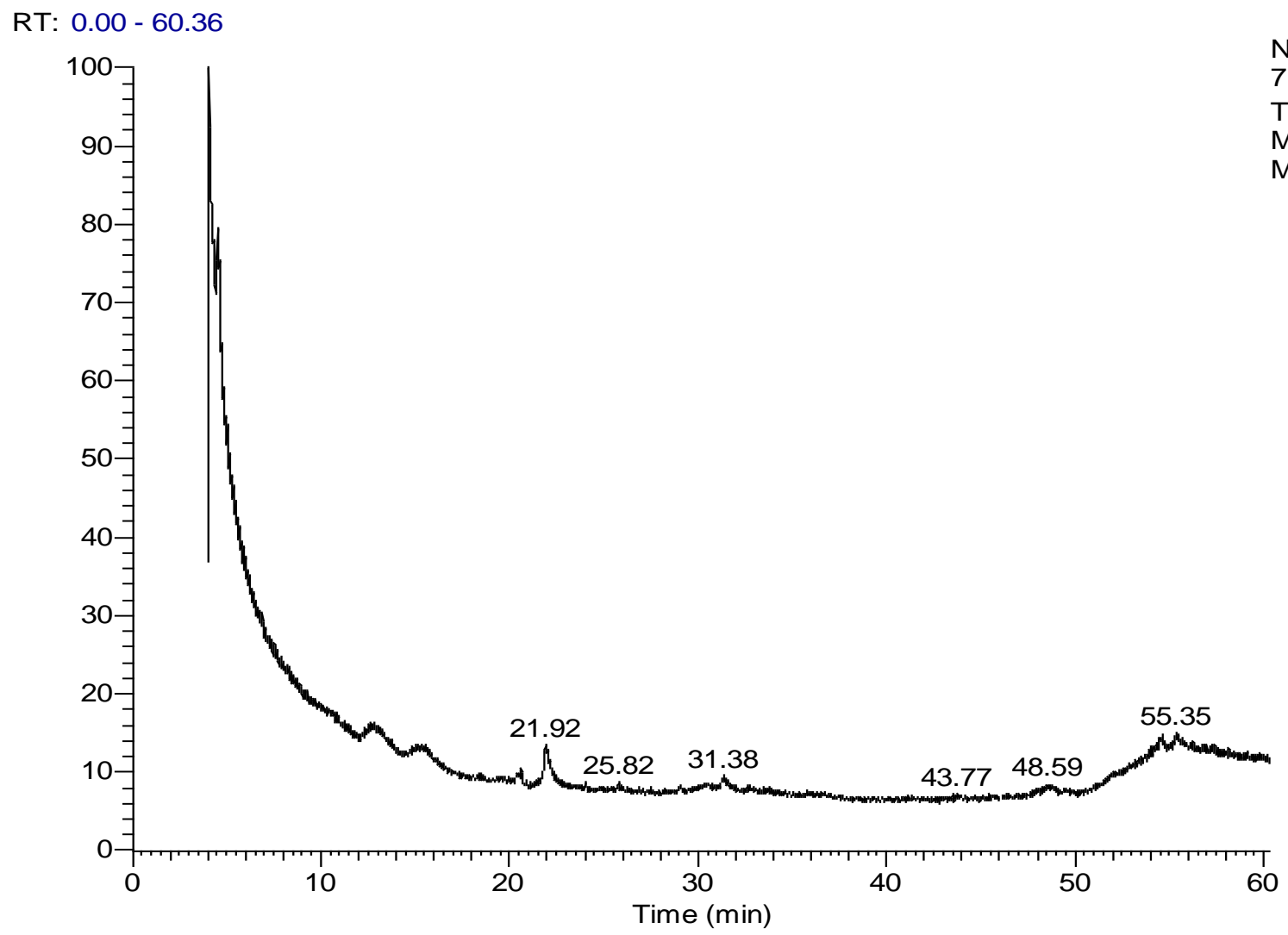

Figure 2. Gas-chromatographic profiles of the urine of male Mus musculus.

Another an interesting point which was also observed from chemical structure of the detected volatile compounds, is the molecular weight of these compounds which were ranged from 94 (phenol) -268 (octadecane, 5 methyl ), our results were supported by those previously obtained by Achiramn and Archunan (2006) whom found that the isolated urinary volatiles in their experiment had a molecular weight less than 300 and carbon atom less than 20 so they regarded these compounds as putative urinary chemo-signal, also dominic (1991) stated that air born chemical substances usually contain 5-20 carbon atom with less than 300 molecular weight to reach the receiver.

\section{Odor preference test}

It is evident from table (3) which showed the response of male and female mice to Phenol, 2-ethyl(CAS) in different concentration that the highest response of the tested animals was to the concentration $100 \%$ (60.07, 56.82 second / visit). \& $5 \%(67.93,55.05$ second / visit) without a significant differences in between.

By testing the attractiveness of Phenol,3-ethylin different concentration $0.5,1,5,10$ and $100 \%$ in both sexes of mice as shown in table (4) data obtained appeared that using of $5 \%$ concentration from this compound is the most effective concentration as the highest no. of visit ( 7 visit) \& the longest time (42.54, 34.52 second / visit) were showed by tested animals toward this concentration.

Statistical analysis of obtained data from testing the odor preference of 4-ethyl phenol by different concentrations in both sexes of mice revealed that concentration $5 \%$ (83.76 second / visit) was the most effective concentration in female mice, while in male mice the concentration $100 \%$ (46.76 second / visit) was the most attractive concentration but without a significant difference between concentrations $100 \%$ $\& 10 \%$ and the $10 \%$ (44.36 second / visit) concentration was not significantly different from concentrate 5\% (38.04 second / visit) as shown in table (5). The present observation gains support from reports related to pheromone identification studies in the mouse by Achiraman and archunan (2002).

When 5-Octadecenal was tested with male \& female mice as shown in table (6) the best results was obtained with concentration of $100 \%$ (40.76 second / visit) in male mice followed by concentration $10 \%$ (38.63 second / visit) \& 5\% (38.63 second / visit) which gave the same results without a significant differences between the three concentrations in case of female mice the best results was observed in concentration 5\% (49.12 second / visit) \& 10\% (49.12 second / visit) which gave identical results. 
Table 3. Bioassay responses of male and female mice to Phenol, 2-ethyl- (CAS) $(0.5,1,5,10$ and $100 \%$ concentrate).

\begin{tabular}{|c|c|c|c|c|c|c|c|c|c|c|c|c|c|}
\hline \multirow{3}{*}{ Compound } & \multirow{3}{*}{ Concentration } & \multicolumn{6}{|c|}{ Male mice } & \multicolumn{6}{|c|}{ female mice } \\
\hline & & \multicolumn{3}{|c|}{ p1 } & \multicolumn{3}{|c|}{ p2 } & \multicolumn{3}{|c|}{ p1 } & \multicolumn{3}{|c|}{ p2 } \\
\hline & & TT & $\mathbf{N V}$ & TT/NV & TT & NV & TT/NV & TT & $\mathbf{N V}$ & TT/NV & TT & NV & TT/NV \\
\hline \multirow{5}{*}{ Phenol, 2-ethyl- (CAS) } & 0.5 & $201.67^{c}$ & 6.67 & $30.35^{c}$ & $162.00^{c}$ & 6.67 & $24.22^{c}$ & $157.00^{b}$ & 6.33 & $24.65^{c}$ & $154.33^{b}$ & 6.67 & $23.10^{c}$ \\
\hline & 1 & $296.00^{b}$ & 7.00 & $43.56^{b}$ & $195.00^{c}$ & 7.33 & $26.76^{c}$ & $233.67^{b}$ & 6.33 & $36.82^{b}$ & $196.33^{b}$ & 6.67 & $29.12^{\mathrm{bc}}$ \\
\hline & 5 & $450.00^{\mathrm{a}}$ & 6.67 & $67.93^{a}$ & $117.33^{c}$ & 6.00 & $19.56^{c}$ & $403.67^{a}$ & 7.33 & $55.05^{a}$ & $136.67^{b}$ & 6.67 & $20.60^{c}$ \\
\hline & 10 & $\mathbf{3 7 3 . 3 3}^{\mathrm{ab}}$ & 6.67 & $56.10^{\mathrm{ab}}$ & $149.00^{c}$ & 6.67 & $22.41^{c}$ & 403.33 & 7.00 & $57.62^{\mathrm{a}}$ & $137.33^{b}$ & 6.67 & $20.61^{c}$ \\
\hline & 100 & $440.33^{a}$ & 7.33 & $60.07^{a}$ & $130.00^{c}$ & 6.00 & $21.45^{c}$ & $400.00^{a}$ & 7.00 & $56.82^{\mathrm{a}}$ & $1^{132.33^{b}}$ & 6.33 & $21.06^{c}$ \\
\hline MSE & - & 29.1 & & 4.29 & 29.1 & & 4.29 & 30.38 & & 3.77 & 30.38 & & 3.77 \\
\hline
\end{tabular}

Table 4. Bioassay responses of male and female mice to Phenol, 3 -ethyl- $(0.5,1,5,10$ and $100 \%$ concentrate $)$.

\begin{tabular}{|c|c|c|c|c|c|c|c|c|c|c|c|c|c|}
\hline \multirow{2}{*}{ Compound } & \multirow{3}{*}{ concentration } & \multicolumn{6}{|c|}{ Male mice } & \multicolumn{6}{|c|}{ female mice } \\
\hline & & \multicolumn{3}{|c|}{ p1 } & \multicolumn{3}{|c|}{ p2 } & \multicolumn{3}{|c|}{ p1 } & \multicolumn{3}{|c|}{ p2 } \\
\hline \multirow{6}{*}{ Phenol, 3-ethyl- } & & TT & NV & TT/NV & TT & $\mathbf{N V}$ & TT/NV & TT & $\mathbf{N V}$ & TT/NV & TT & NV & TT/NV \\
\hline & 0.5 & $162.00^{c d}$ & 7.33 & $22.03^{\text {bc }}$ & $135.67^{d}$ & 7.00 & $19.38^{c}$ & $150.67^{b}$ & 6.67 & $22.49^{b}$ & $153.67^{b}$ & 7.00 & $21.95^{b}$ \\
\hline & 1 & $203.33^{b c}$ & 7.67 & $26.73^{b}$ & $175.33^{c d}$ & 7.00 & $25.05^{\mathrm{bc}}$ & $177.67^{b}$ & 7.00 & $24.92^{b}$ & $160.67^{b}$ & 7.00 & $22.95^{b}$ \\
\hline & 5 & $299.33^{a}$ & 7.00 & $42.54^{a}$ & $154.00^{\mathrm{cd}}$ & 7.00 & $22.01^{\text {bc }}$ & $241.00^{\mathrm{a}}$ & 7.00 & $34.52^{\mathrm{a}}$ & $151.67^{b}$ & 6.67 & $22.73^{b}$ \\
\hline & 10 & $234.00^{b}$ & 6.33 & $36.95^{\mathrm{a}}$ & $139.33^{d}$ & 6.33 & $21.98^{b c}$ & $231.00^{\mathrm{a}}$ & 7.00 & $33.00^{\mathrm{a}}$ & $146.67^{b}$ & 6.33 & $23.08^{b}$ \\
\hline & 100 & $238.33^{b}$ & 6.33 & $37.68^{a}$ & $130.67^{d}$ & 6.00 & $21.78^{\text {bc }}$ & $234.67^{a}$ & 6.67 & $35.37^{a}$ & $134.00^{b}$ & 6.00 & $22.33^{b}$ \\
\hline MSE & - & 18.73 & & 2.02 & 18.73 & & 2.02 & 16.35 & & 1.78 & 16.35 & & 1.78 \\
\hline
\end{tabular}

data are presented as means \pm standerd error. Mean followed by different letters in each column are significantly $(\mathrm{p}<0.05)$ different. 
Table 5. Bioassay responses of male and female mice to 4 -ethyl phenol $(0.5,1,5,10$ and $100 \%$ concentrate $)$.

\begin{tabular}{|c|c|c|c|c|c|c|c|c|c|c|c|c|c|}
\hline \multirow{3}{*}{ Compound } & \multirow{3}{*}{ concentration } & \multicolumn{6}{|c|}{ Male mice } & \multicolumn{6}{|c|}{ female mice } \\
\hline & & \multicolumn{3}{|c|}{ p1 } & \multicolumn{3}{|c|}{ p2 } & \multicolumn{3}{|c|}{ p1 } & \multicolumn{3}{|c|}{ p2 } \\
\hline & & TT & NV & TT/NV & TT & $\mathbf{N V}$ & TT/NV & TT & NV & TT/NV & TT & NV & TT/NV \\
\hline \multirow{5}{*}{ 4-ethyl phenol } & 0.5 & $153.33^{c}$ & 7.33 & $20.80^{c}$ & $149.33^{c}$ & 7.00 & $21.33^{c}$ & $181.33^{c}$ & 7.00 & $25.90^{\text {bc }}$ & $177.33^{\text {bc }}$ & 7.00 & $25.33^{\text {bc }}$ \\
\hline & 1 & $183.00^{c}$ & 7.33 & $24.85^{c}$ & $171.67^{\mathrm{c}}$ & 6.67 & $25.50^{c}$ & $273.33^{b}$ & 7.00 & $39.05^{b}$ & $232.67^{b c}$ & 7.00 & $33.24^{\mathrm{bc}}$ \\
\hline & 5 & $265.33^{b}$ & 7.00 & $38.04^{b}$ & $146.00^{c}$ & 6.67 & $21.94^{c}$ & $586.33^{a}$ & 7.00 & 83.76 $^{\mathrm{a}}$ & $134.00^{c}$ & 6.33 & $21.30^{c}$ \\
\hline & 10 & $310.33^{a b}$ & 7.00 & $44.36^{\mathrm{a}}$ & $134.33^{c}$ & 6.33 & $21.35^{\mathrm{c}}$ & $527.67^{a}$ & 7.33 & $71.65^{a}$ & $131.67^{c}$ & 6.33 & $20.95^{c}$ \\
\hline & 100 & $342.00^{\mathrm{a}}$ & 7.33 & $46.76^{a}$ & $126.67^{c}$ & 6.33 & $20.12^{c}$ & $562.00^{a}$ & 7.00 & $81.14^{a}$ & $132.67^{c}$ & 6.33 & $21.05^{c}$ \\
\hline MSE & - & 18.77 & & 2.12 & 18.77 & & 2.12 & 37.74 & & 5.30 & 37.74 & & 5.30 \\
\hline
\end{tabular}

Table 6. Bioassay responses of male and female mice to 5-Octadecenal $(0.5,1,5,10$ and $100 \%$ concentrate).

\begin{tabular}{|c|c|c|c|c|c|c|c|c|c|c|c|c|c|}
\hline \multirow{3}{*}{ Compound } & \multirow{3}{*}{ concentration } & \multicolumn{6}{|c|}{ Male mice } & \multicolumn{6}{|c|}{ female mice } \\
\hline & & \multicolumn{3}{|c|}{ p1 } & \multicolumn{3}{|c|}{ p2 } & \multicolumn{3}{|c|}{ p1 } & \multicolumn{3}{|c|}{ p2 } \\
\hline & & TT & NV & TT/NV & TT & $\mathbf{N V}$ & TT/NV & TT & NV & TT/NV & TT & NV & TT/NV \\
\hline \multirow{5}{*}{ 5-Octadecenal } & 0.5 & $256.00^{\mathrm{a}}$ & 6.67 & $38.63^{a}$ & $151.67^{b}$ & 6.67 & $22.75^{b}$ & $177.67^{\mathrm{bc}}$ & 6.67 & $26.74^{b}$ & $145.33^{c}$ & 6.33 & $23.16^{b}$ \\
\hline & 1 & $167.67^{b}$ & 6.67 & $25.22^{b}$ & $137.00^{b}$ & 6.67 & $20.67^{b}$ & $218.33^{b}$ & 7.67 & $28.66^{b}$ & $181.00^{b c}$ & 7.67 & $23.53^{b}$ \\
\hline & 5 & $256.00^{a}$ & 6.67 & $38.63^{a}$ & $151.67^{b}$ & 6.67 & $22.75^{b}$ & $309.00^{\mathrm{a}}$ & 6.33 & $49.12^{\mathrm{a}}$ & $155.67^{c}$ & 6.33 & $24.56^{b}$ \\
\hline & 10 & $256.00^{a}$ & 6.67 & $38.63^{a}$ & $150.33^{b}$ & 6.67 & $22.55^{b}$ & $309.00^{\mathrm{a}}$ & 6.33 & $49.12^{\mathrm{a}}$ & $148.67^{c}$ & 6.67 & $22.37^{b}$ \\
\hline & 100 & $285.33^{a}$ & 7.00 & $40.76^{a}$ & $144.00^{b}$ & 6.67 & $21.58^{b}$ & $298.00^{a}$ & 6.33 & $47.49^{\mathrm{a}}$ & $143.00^{c}$ & 6.67 & $21.52^{b}$ \\
\hline MSE & - & 17.05 & & 2.69 & 17.05 & & 2.69 & 15.24 & & 2.80 & 15.24 & & 2.80 \\
\hline
\end{tabular}

$\mathrm{P}=$ Passage in Y-maze apparatus. $\quad \mathrm{T}=$ The time spent /second in one visit. $\mathrm{N}=$ The number visits of passage. To.T $=$ Total time spent in passage

are presented as means \pm standerd error. Mean followed by different letters in each column are significantly $(\mathrm{p}<0.05)$ different. 
Bioassay analysis of Octadecane,5-methylin mice revealed that the most attractant concentration was concentration 5\% (27.93, 28.06 second / visit) which cause mice to spend long time beside this material in both sexes as shown in table (7).

Regarding the effect of 1,8-Nonadien-3-olon mice, results of male mice revealed that the longest staying time was observed with concentration $10 \%$ (28.52 second / visit) but without significant statistical differences between different concentrations so the least concentration $0.5 \%$ (28.50 second / visit) has the same effect of $100 \%$ (23.72 second / visit) concentration on male mice. In the female mice the longest staying time was achieved with concentration 5\% (59.71 second / visit) but without significant differences with concentration 10\% (53.71 second / visit) table (8).

Some of our detected volatile compounds like 1,8-Nonadien-3-ol were not reported in the available literature but generally we can consider them as pheromones depending upon their volatile nature and the number of their carbon atom and molecular weight and according to what had been reported by Ramesh Kumar et al (2000); Kannan and Archnan (2001); Selvaraj and Archnan (2002).

General view on the bioassay responses of male and female mice to identified compounds (Phenol,2-ethyl- (CAS), Phenol, 3-ethyl-, 4-ethyl phenol, 5-Octadecenal, Octadecane,5-methyl, 1,8Nonadien-3-ol) as showed in table(9) demonstrated that in male mice Phenol, 2-ethyl- (CAS) is the most attracting material as male mice stayed time in one visit of 67.93 second / visit exploring this material followed by Phenol, 3-ethyl which consumed time of 42.54 second / visit investigating this material, in case of female mice 4-ethyl phenol was the best attracting material as female mice spent 83.76 second / visit beside this material. The second attracting material was 1,8-Nonadien-3-ol \& Phenol, 2-ethyl- (CAS) as female mice stayed inside the arm of $\mathrm{Y}$ maze apparatus containing this material for 59.71,55.05 second / visit. Obtained data revealed that two materials with high attracting property were common between both sexes and this facilitates the use of one of them in mice control hence solve the problem of use of deferent chemical material in rodent control so reduce the cost of rodent combating.

\section{Effect of mixing of identified compounds with formulated feed on food Consumption}

Results obtained from addition of identified compounds at concentrations of 1 and $5 \%$ by two concentrations (10 and 20\%) to mice ration as showed in table (10) reveal that food consumption was increased in male mice when their food were mixed with 4-ethyl phenol $5 \%$ at $20 \%$ and $10 \%$ concentration and 4-ethyl phenol $1 \%$ at $20 \%$ and $10 \%$ concentration, Phenol, 2-ethyl- (CAS) $5 \%$ at $20 \%$ and $10 \%$ concentration and Phenol, 2-ethyl- (CAS) $1 \%$ at $20 \%$ and $10 \%$ concentration, Phenol, 3 -ethyl- 5\% at
$20 \%$ and $10 \%$ concentration and Phenol, 3-ethyl-1\% at $20 \%$ and $10 \%$ concentration and 2-Cyclohexen-1ol, 3-methyl- $5 \%$ at $20 \%$ and $10 \%$ concentration and 2-Cyclohexen-1-ol, 3-methyl- $1 \%$ at $20 \%$ and $10 \%$ concentration $(14.9,13.5,13.3,12.7,14.6,13.6,14.7$, $12.2,13.5,12.6,12.5,11.8,12.8,12.7,12.4,11.7$ $\mathrm{g} / 100 \mathrm{~g}$ body weight respectively), but in female mice was increased when their food was mixed with 4-ethyl phenol $5 \%$ at $20 \%$ and $10 \%$ concentration and 4-ethyl phenol $1 \%$ at $20 \%$ and $10 \%$ concentration, 2Cyclohexen-1-ol, 3-methyl- 5\% at $20 \%$ and $10 \%$ concentration and 2-Cyclohexen-1-ol, 3-methyl- 1\% at $20 \%$ and $10 \%$ concentrate, 1,8-Nonadien-3-ol 5\% at $20 \%$ and $10 \%$ concentration and 1,8-Nonadien-3ol $1 \%$ at $20 \%$ and $10 \%$ concentration and 5Octadecenal $5 \%$ at $20 \%$ and $10 \%$ concentration and 5-Octadecenal $1 \%$ at $20 \%$ and $10 \%$ concentration $(14.67,14.45,14,13.64,14.33,14.24,13.64,12.73$, $13.81,14.29,14.1,13,14.24,13.74,13.58,13.47$ $\mathrm{g} / 100 \mathrm{~g}$ body weight respectively). General view on the obtained date revealed that not all the detected volatile substances have the same effect but there are differences in their effectiveness when added to mice ration.

Our results were supported by data published by Omar et al. (1990) who found that urine-treated food was more palatable, than untreated food, for all rat groups. On the other hand, palatability was higher when rat urine was collected from different sex groups than rom the same sex group, which indicates the possible effect of sex and aggressive promotion pheromones that exist in rat urine of both sexes, also Soni and Prakash (1987) in their study on the softfurred field-rat, Rattus meltada pallidior they found that rats preferred millet in which $1 \%$ conspecific urine, either of male or female, was added indicating that conspecific urine or its odour functions as phagostimulant for this rodent. Evaluation of the responses of male and female mice towards the urine odour of the either sex revealed that they prefer unisex odour. 
Table 7. Bioassay responses of male and female mice to Octadecane, 5 -methyl- $(0.5,1,5,10$ and $100 \%$ concentrate $)$.

\begin{tabular}{|c|c|c|c|c|c|c|c|c|c|c|c|c|c|}
\hline \multirow{3}{*}{ Compound } & \multirow{3}{*}{ concentration } & \multicolumn{6}{|c|}{ Male mice } & \multicolumn{6}{|c|}{ female mice } \\
\hline & & \multicolumn{3}{|c|}{ p1 } & \multicolumn{3}{|c|}{ p2 } & \multicolumn{3}{|c|}{ p1 } & \multicolumn{3}{|c|}{ p2 } \\
\hline & & TT & NV & TT/NV & TT & NV & TT/NV & TT & NV & TT/NV & TT & NV & TT/NV \\
\hline \multirow{5}{*}{ Octadecane, 5-methyl- } & 0.5 & $164.00^{\mathrm{a}}$ & 6.33 & $26.08^{a b}$ & $105.67^{b}$ & 6.00 & $17.61^{d}$ & $151.33^{a b}$ & 6.33 & $23.72^{\mathrm{a}}$ & $134.00^{\mathrm{ab}}$ & 6.67 & $20.10^{\mathrm{a}}$ \\
\hline & 1 & $169.00^{\mathrm{a}}$ & 7.00 & $24.14^{\text {abc }}$ & $121.67^{b}$ & 7.33 & $16.74^{d}$ & $156.00^{\mathrm{ab}}$ & 6.67 & $23.30^{\mathrm{a}}$ & $133.00^{\text {ab }}$ & 6.67 & $20.11^{\mathrm{a}}$ \\
\hline & 5 & $177.00^{\mathrm{a}}$ & 6.33 & $27.93^{\mathrm{a}}$ & $125.33^{\mathrm{b}}$ & 6.00 & $20.89^{\text {cd }}$ & $178.33^{a}$ & 6.33 & $28.06^{a}$ & $150.67^{a b}$ & 6.67 & $22.56^{\mathrm{a}}$ \\
\hline & 10 & $174.00^{\mathrm{a}}$ & 6.00 & $29.05^{a}$ & $142.67^{a b}$ & 6.67 & $21.30^{\text {bcd }}$ & $167.67^{a b}$ & 6.33 & $26.29^{a}$ & $139.67^{a b}$ & 6.33 & $21.94^{a}$ \\
\hline & 100 & $168.33^{\mathrm{a}}$ & 6.33 & $26.56^{a}$ & $114.00^{b}$ & 5.67 & $20.27^{\mathrm{cd}}$ & $160.67^{a b}$ & 6.00 & $26.75^{a}$ & $123.33^{\mathrm{b}}$ & 5.67 & $21.66^{\mathrm{a}}$ \\
\hline MSE & - & 11.84 & & 1.60 & 11.84 & & 1.60 & 16.04 & & 1.60 & 16.04 & & 1.60 \\
\hline
\end{tabular}

Table 8. Bioassay responses of male and female mice to 1,8-Nonadien-3-ol $(0.5,1,5,10$ and $100 \%$ concentrate $)$.

\begin{tabular}{|c|c|c|c|c|c|c|c|c|c|c|c|c|c|}
\hline \multirow{3}{*}{ Compound } & \multirow{3}{*}{ concentration } & \multicolumn{6}{|c|}{ Male mice } & \multicolumn{6}{|c|}{ female mice } \\
\hline & & \multicolumn{3}{|c|}{ p1 } & \multicolumn{3}{|c|}{ p2 } & \multicolumn{3}{|c|}{ p1 } & \multicolumn{3}{|c|}{ p2 } \\
\hline & & TT & $\mathbf{N V}$ & TT/NV & TT & NV & TT/NV & TT & NV & TT/NV & TT & NV & TT/NV \\
\hline \multirow{5}{*}{ 1,8-Nonadien-3-ol } & 0.5 & $171.00^{\mathrm{a}}$ & 6.00 & $28.50^{\mathrm{a}}$ & $148.00^{\text {abc }}$ & 6.33 & $23.24^{\mathrm{abc}}$ & $200.67^{\mathrm{de}}$ & 6.67 & $30.29^{d}$ & $143.67^{\mathrm{e}}$ & 6.67 & $21.50^{\mathrm{e}}$ \\
\hline & 1 & $167.00^{a b}$ & 6.00 & $27.83^{\mathrm{ab}}$ & $127.33^{\mathrm{cd}}$ & 6.00 & $21.22^{\mathrm{cd}}$ & $259.67^{c d}$ & 7.00 & $37.43^{c d}$ & $162.00^{\mathrm{e}}$ & 7.00 & $23.14^{\mathrm{e}}$ \\
\hline & 5 & $155.33^{a b}$ & 6.33 & $24.66^{\mathrm{abc}}$ & $132.33^{\text {cd }}$ & 6.00 & $22.06^{\text {cd }}$ & $395.00^{\mathrm{a}}$ & 6.67 & $59.71^{\mathrm{a}}$ & $152.33^{e}$ & 6.67 & $22.88^{e}$ \\
\hline & 10 & $209.33^{\mathrm{a}}$ & 7.33 & $28.52^{\mathrm{a}}$ & $116.67^{d}$ & 6.33 & $18.60^{d}$ & $376.00^{a b}$ & 7.00 & $53.71^{\mathrm{ab}}$ & $161.67^{\mathrm{e}}$ & 7.00 & $23.10^{\mathrm{e}}$ \\
\hline & 100 & $148.67^{a b}$ & 6.33 & $23.72^{\text {abc }}$ & $131.33^{\text {cd }}$ & 6.33 & $20.72^{\text {cd }}$ & $367.00^{b}$ & 6.67 & $55.18^{\mathrm{ab}}$ & $161.67^{\mathrm{e}}$ & 6.67 & $24.19^{e}$ \\
\hline MSE & - & 10.66 & & 1.70 & 10.66 & & 1.70 & 27.82 & & 3.66 & 27.82 & & 3.66 \\
\hline
\end{tabular}

are presented as means \pm standerd error. Mean followed by different letters in each column are significantly $(\mathrm{p}<0.05)$ different. 
Table 9. Bioassay responses of male and female mice to identified compounds (5\% concentrate).

\begin{tabular}{|c|c|c|c|c|c|c|c|c|c|c|c|c|}
\hline \multirow{3}{*}{$\begin{array}{c}\text { Concentration } \\
\mathbf{5 \%}\end{array}$} & \multicolumn{6}{|c|}{ Male mice } & \multicolumn{6}{|c|}{ female mice } \\
\hline & \multicolumn{3}{|c|}{ p1 } & \multicolumn{3}{|c|}{ p2 } & \multicolumn{3}{|c|}{ p1 } & \multicolumn{3}{|c|}{ p2 } \\
\hline & TT & $\mathbf{N V}$ & TT/NV & TT & $\mathbf{N V}$ & TT/NV & TT & $\mathbf{N V}$ & TT/NV & TT & $\mathbf{N V}$ & TT/NV \\
\hline Phenol, 2-ethyl- (CAS) & $450.00^{\mathrm{a}}$ & 6.67 & $67.93^{a}$ & $117.33^{f}$ & 6.00 & $19.56^{\mathrm{e}}$ & $403.67^{b}$ & 7.33 & $55.05^{b}$ & $136.67^{g}$ & 6.67 & $20.60^{\mathrm{g}}$ \\
\hline Phenol, 3-ethyl- & $299.33^{b}$ & 7.00 & $42.54^{b}$ & $154.00^{\text {ef }}$ & 7.00 & $22.01^{\mathrm{e}}$ & $241.00^{\mathrm{de}}$ & 7.00 & $34.52^{d}$ & $151.67^{f}$ & 6.67 & $22.73^{\mathrm{g}}$ \\
\hline 4-ethyl phenol & $265.33^{b}$ & 7.00 & $38.04^{\mathrm{c}}$ & $146.00^{\text {ef }}$ & 6.67 & $21.94^{\mathrm{e}}$ & $586.33^{\mathrm{a}}$ & 7.00 & $83.76^{a}$ & $134.00^{\mathrm{g}}$ & 6.33 & $21.30^{\mathrm{g}}$ \\
\hline 5-Octadecenal & $256.00^{\mathrm{cd}}$ & 6.67 & $38.63^{c}$ & $151.67^{\mathrm{ef}}$ & 6.67 & $22.75^{\mathrm{e}}$ & $309.00^{c}$ & 6.33 & $49.12^{c}$ & $155.67^{f}$ & 6.33 & $24.56^{\mathrm{g}}$ \\
\hline Octadecane, 5-methyl- & $177.00^{\mathrm{e}}$ & 6.33 & $27.93^{d}$ & $125.33^{f}$ & 6.00 & $20.89^{e}$ & $178.33^{f}$ & 6.33 & $28.06^{\mathrm{d}}$ & $150.67^{f}$ & 6.67 & $22.56^{\mathrm{g}}$ \\
\hline 1,8-Nonadien-3-ol & $155.33^{\text {ef }}$ & 6.33 & $24.66^{\text {de }}$ & $132.33^{\mathrm{f}}$ & 6.00 & $22.06^{\mathrm{e}}$ & $395.00^{b}$ & 6.67 & $59.71^{\mathrm{b}}$ & $152.33^{\mathrm{f}}$ & 6.67 & $22.88^{\mathrm{g}}$ \\
\hline MSE & 18.23 & & 2.34 & 18.23 & & 2.34 & 15.15 & & 2.02 & 15.15 & & 2.02 \\
\hline
\end{tabular}

are presented as means \pm standerd error. Mean followed by different letters in each column are significantly $(p<0.05)$ different. 
Table 10. Food consumption (gm) in male and female mice as affected by the type and concentration of identified compounds mixed with food $(10,20 \%$ concentrate $)$

\begin{tabular}{|c|c|c|c|}
\hline treatment & Conc. & male mice & female mice \\
\hline \multirow{2}{*}{ Phenol, 2-ethyl- (CAS) 1\% } & $10 \%$ & $12.2^{\mathrm{ab}}$ & $11.94^{b}$ \\
\hline & $20 \%$ & $14.7^{\mathrm{a}}$ & $12.37^{\mathrm{b}}$ \\
\hline \multirow{2}{*}{ Phenol, 2-ethyl- (CAS) 5\% } & $10 \%$ & $13.6^{\mathrm{a}}$ & $11.32^{b}$ \\
\hline & $20 \%$ & $14.6^{\mathrm{a}}$ & $12.12^{b}$ \\
\hline \multirow{2}{*}{ Phenol, 3-ethyl- 1\% } & $10 \%$ & $11.8^{b}$ & $8.77^{\mathrm{c}}$ \\
\hline & $20 \%$ & $12.5^{\mathrm{ab}}$ & $9.333^{\mathrm{c}}$ \\
\hline \multirow{2}{*}{ Phenol, 3-ethyl- 5\% } & $10 \%$ & $12.6^{\mathrm{ab}}$ & $8.876^{c}$ \\
\hline & $20 \%$ & $13.5^{\mathrm{a}}$ & $9.41^{\mathrm{c}}$ \\
\hline \multirow{2}{*}{ 4-ethyl phenol $1 \%$} & $10 \%$ & $12.7^{\mathrm{ab}}$ & $13.64^{\mathrm{a}}$ \\
\hline & $20 \%$ & $13.3^{\mathrm{a}}$ & $14.00^{\mathrm{a}}$ \\
\hline \multirow{2}{*}{ 4-ethyl phenol 5\% } & $10 \%$ & $13.5^{\mathrm{a}}$ & $14.45^{\mathrm{a}}$ \\
\hline & $20 \%$ & $14.9^{\mathrm{a}}$ & $14.67^{a}$ \\
\hline \multirow{2}{*}{ 5-Octadecenal $1 \%$} & $10 \%$ & $10.7^{\mathrm{bc}}$ & $13.47^{\mathrm{a}}$ \\
\hline & $20 \%$ & $8.15^{d}$ & $13.58^{\mathrm{a}}$ \\
\hline \multirow{2}{*}{ 5-Octadecenal 5\% } & $10 \%$ & $9.47^{\mathrm{c}}$ & $13.74^{\mathrm{a}}$ \\
\hline & $20 \%$ & $9.86^{c}$ & $14.24^{\mathrm{a}}$ \\
\hline \multirow[t]{2}{*}{ Octadecane, 5-methyl- $1 \%$} & $10 \%$ & $9.14^{\mathrm{c}}$ & $8.754^{c}$ \\
\hline & $20 \%$ & $9.39^{c}$ & $8.79^{c}$ \\
\hline \multirow[t]{2}{*}{ Octadecane, 5-methyl- 5\% } & $10 \%$ & $8.35^{d}$ & $10.02^{b c}$ \\
\hline & $20 \%$ & $7.58^{\mathrm{e}}$ & $8.183^{d}$ \\
\hline \multirow{2}{*}{ 1,8-Nonadien-3-ol $1 \%$} & $10 \%$ & $9.19^{c}$ & $13^{\mathrm{ab}}$ \\
\hline & $20 \%$ & $9.23^{\mathrm{c}}$ & 14.1a \\
\hline \multirow{2}{*}{ 1,8-Nonadien-3-ol $5 \%$} & $10 \%$ & $10.4^{\mathrm{bc}}$ & $14.29^{\mathrm{a}}$ \\
\hline & $20 \%$ & $7.89^{\mathrm{de}}$ & $13.81^{\mathrm{a}}$ \\
\hline mse & & 0.59 & 0.55 \\
\hline
\end{tabular}

\section{References}

Achiraman, S. and Archunan, G. (2002). Characterization of urinary volatiles in Swiss male mice (Mus musculus): Bioassay of identified compounds. 27, ( 7): 679-686 .

Achiraman, S. and Archunan, G. (2006).1-Iodo2methylundecane, a putative estrus-specific urinary chemo-signal of female mouse (Mus musculus).Theriogenology 66: 1913-1920

Cavaggioni A and Mucignat-Caretta C (2000). Major urinary proteins, a2U-globulins and aphrodisin; Biochem. Biophys. Acta 1482(12):218-28.

Dominic, C J. (1991). Chemical communication in animals; J. Sci. Res. 41 157-169.

Duncan, D.B. (1955). Multiple range and multiple F.test J.B Biometries, 11(1).

Jackson, WB. (1987). Current management studies for commensal rodents. In HH Genoways, ed. Current mammalogy, Vol. 1. New York: Plenum Publishing. pp.495-512.
Kannan, S. and Archunan, G. (2001). Chemistry of clitoral gland secretions of the laboratory rat: assessment of behavioural response to identified compounds. Journal of Biosciences. 26(2):247-52.

Kumara S. and Prakash I (1980). Role of conspecific urine in enhancing food consumption \& masking of shyness behaviour in the desert gerbil Meriones hurrianae (Jerdon). Indian journal of experimental biology 18(7):730-2

Novotny M, Jemiolo B, Harvey S, Wiesler D and MarchleswkaKoj A (1985). Adrenal mediated endogenous metabolites inhibiting puberty in female mice. Science. 231(4739):722-5.

Omar, A. M.; El-sherbiny, A. H.; El-Deeb, H. I. and El-Halfawy, M. (1990). Laboratory studies on the function of rat urine as aphagostimulant. Assiut Journal of Agricultural Sciences. 21(4), 49-61.

Ramesh Kumar K, Archunan G, Jeyaraman R and Narashimman $S \quad$ (2000) Chemical 
characterization of Bovine urine with special reference to oestrus. Vet Res Commun.24(7):445-54.

SAS, (2004). SAS User's Guide: Statistics. Version 9.1.SAS Inst. Inc., Cary, NC.,USA.

Selvaraj, R. and Archunan, G. (2002). Chemical identification and bioactivity of rat (Rattus rattus) urinary compounds. Zoological Studies 41(2): 127-135.

Soni, GR. and Prakash, I. (1987). Effect of conspecific urine odour on behaviour of softfurred field rat, Rattus meltada. Behav. Process. 14: 175-182.

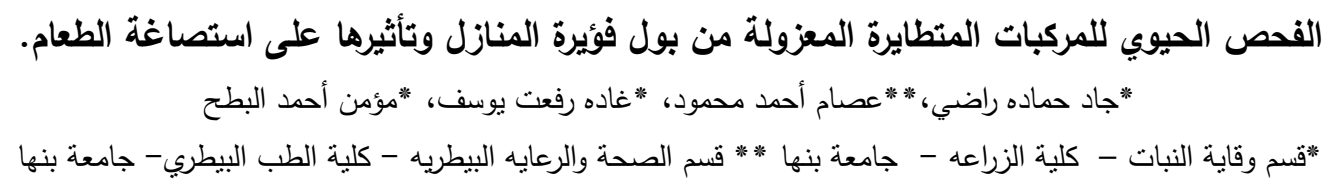

